Nuntius Antiquus, Belo Horizonte, v. 12, n. 1, p. 69-89, 2016

\title{
Éros em perspectiva: refutação e filosofia no Fedro de Platão
}

\section{Eros on perspective: refutation and philosophy in Plato's Phaedrus}

\author{
Venúncia Emília Coelho \\ Instituto Federal de Minas Gerais - IFMG \\ Ouro Preto, MG - Brasil \\ venuncia@yahoo.com.br
}

Resumo: O objetivo principal deste artigo é analisar os três discursos sobre éros apresentados no Fedro, problematizando em que medida a disputa que ocorre na primeira metade do texto pode ser articulada com as discussões pontuais acerca da prática retórica e da correta técnica de composição de discursos, presentes na segunda parte do diálogo. Para tanto, apresenta uma estratégia de leitura dinâmica que busca apresentar algumas soluções para o problema da unidade do Fedro. Dessa maneira, espera-se contribuir para a discussão relacionada ao modo como a temática do amor e da retórica se articulam dentro do diálogo.

Palavras-chave: éros; retórica; filosofia; Fedro.

Abstract: The aim of this paper is to analyze the three speeches about eros presented in the Phaedrus, questioning to what extent the dispute that takes place in the first half of the text can be linked to the specific discussions of rhetorical practice and the proper technique of composing speeches, found in the second part of the dialogue. It presents a dynamic reading strategy that seeks to present some solutions to the problem of the unity of the Phaedrus. This way, it is expected to contribute to the discussion related to how the theme of love and rhetoric are articulated within the dialogue.

Keywords: eros; rhetoric; philosophy; Phaedrus. 
Artigo recebido em 10 de agosto de 2015 Aprovado para publicação em 20 de outubro de 2015

As primeiras páginas do Fedro não deixam dúvidas de que o assunto em pauta é o amor. O discurso de Lísias e os dois discursos de Sócrates versam sobre o tema de éros, mais propriamente sobre se é preferível relacionar-se com parceiros apaixonados ou não. Mesmo que, do início até o final da primeira metade do diálogo, o assunto almejado seja o amor, no segundo discurso de Sócrates, a temática sofre sua primeira variação, voltando-se à investigação para a análise do delírio (manía), que, conforme o filósofo, é o tópico central que deve ser considerado nas discussões acerca das consequências e propriedades do afeto erótico. Aqui surge o dilema que nos interessa explorar: como conciliar os três discursos sobre éros (231a-257c) apresentados na primeira parte do Fedro com as discussões propositivas acerca da natureza do discurso e da retórica, levadas a cabo na sua segunda parte (257a-279e)? Proponho, como pressuposto interpretativo, que os três discursos sobre o amor encarnam indiretamente a temática da retórica, tal como é desenvolvida na segunda parte do diálogo, porém de modo dramático, na medida em que coloca em ação a proposta socrática de uma boa prática persuasiva e mostra a necessidade da refutação para o estabelecimento de teses e crítica dos discursos exclusivamente destinados a persuadir.

O tema do amor aparece, objetivamente, nos três discursos que compõem o diálogo. Lísias fala de éros, ao passo que Sócrates primeiramente parodia o logógrafo para depois construir seu discurso de retratação. O Fedro, quando fala de éros, o faz por meio de uma disputa retórica entre Lísias e Sócrates, evidenciando a necessidade de não somente compor discursos eficazes, mas que ambicionem ser verdadeiros. Por assunto central entende-se não o tema único, mas o tópico que unifica e confere sentido à variabilidade das abordagens. Nesse sentido, o Fedro é um diálogo sobre retórica, direta e indiretamente. É diretamente sobre retórica na medida em que a trata como assunto teórico, atribuindo-lhe características pontuais, principalmente na segunda metade do diálogo. É indiretamente sobre retórica porque coloca em prática, por intermédio do embate entre os discursos de Sócrates e Lísias, o uso eficaz e filosófico da dimensão persuasiva da linguagem. Também porque, fazendo uso da argumentação, traz à tona um exemplo de refutação moldado pelas exigências de uma nova maneira de persuadir. Isso não significa que a 
escolha pelo tema de éros possa ser percebida como aleatória, ou seja, que Platão pudesse optar por qualquer outro assunto sem um prejuízo para a construção conceitual.

Paradoxalmente, o tema de éros, objeto de composição dos três discursos na primeira parte do diálogo e motivo da disputa entre Lísias e Sócrates, desaparece das discussões na segunda parte, a partir de $257 \mathrm{~b}$. O paradoxo é desfeito quando compreendemos que exatamente quando éros sai de cena, na segunda metade do diálogo, é que ele ainda está presente, pois, após a caraterização da alma na palinódia, a justificativa da prática filosófica e retórica deverá passar necessariamente pela dimensão desiderativa, não sendo possível nem refutar nem mesmo compor e escrever belos discursos sem a presença de uma alma que deseja o conhecimento e a verdade. No Fedro, de modo muito semelhante ao Elogio gorgiano, tudo é sobre éros e tudo também é sobre o discurso. Quando Górgias fala de Helena, fala sincronicamente de éros e discursa, sobremaneira, sobre o ato de discursar. Entretanto, para investigar a unidade do diálogo, é necessário que se pergunte o porquê de tal mudança e em que medida a escolha pelo tema de éros pode ser relacionada com os tópicos tratados na segunda parte do Fedro. Em outras palavras, como interligar o tema do amor às discussões posteriores sobre a retórica? É possível pensar uma unidade de significados entre os temas da retórica e do amor?

Werner Jaeger sugere que a escolha platônica pelo tema do amor é ocasional. Por se tratar de assunto geral e bastante discutido em exercícios de erística, Jaeger (2011, p. 1259) acredita que a escolha por éros não passa de um movimento aleatório. Se o filólogo alemão estiver certo, deveria ser possível imaginar o mesmo diálogo iniciando suas discussões a partir da escolha de outro tema qualquer. Hackforth mantém outra interpretação sobre a unidade do Fedro e o papel de éros no diálogo. Segundo o estudioso, "para Platão filosofia é amor" (1972, p. 10) e ele sempre se personifica por meio do desejo em direção à completude da alma representada pela busca filosófica. Se éros não garante o filosofar por si só, ele participa decisivamente daquilo que move a alma no desejo pelo saber. Diferente de Jaeger e Hackforth, pensamos que a escolha pela temática de éros relaciona-se diretamente com o assunto central do diálogo, a saber, a retórica, pois traz à baila na palinódia uma discussão fundamental sobre a caracterização da alma e o modo como os discursos devem se adequar àquilo que lhes é mais peculiar. Ocorre que éros é um tema afim e propício aos outros tópicos 
tratados e dá a oportunidade certeira para que Sócrates construa um discurso sobre a natureza da alma humana. Ocorre também que éros é o tema oportuno para atingir Fedro, o jovem que acabou de ser enredado por um discurso insidioso, composto por Lísias. Não se poderia falar de outra coisa, não com Fedro que acabara de ouvir o lógos de Lísias. O senso de oportunidade não somente determina a escolha do tema, mas estabelece a relação ideal para que Sócrates desenvolva sua psicologia na palinódia. As ponderações de cunho psicológico desenvolvidas na palinódia são de extrema importância para caracterizar os tipos de alma e o modo como cada uma delas é afetada. A caracterização e tipificação das almas, bem como a investigação acerca de sua natureza, é o ponto de partida para o estabelecimento de uma nova prática retórica que deve ser, ao mesmo tempo, a prática filosófica e dialética, na medida em que precisa buscar definições e investigar questões em aberto. Vejamos mais de perto os discursos antagônicos sobre o amor.

\section{0 lógos de Lísias}

Segundo Fedro, o conteúdo do discurso de Lísias é controverso. O assunto é o amor e é direcionado a um auditório específico: um rapaz apaixonado. O objetivo de Lísias é duplo. Por um lado e de maneira declarada, o discurso ambiciona provar a tese de que é melhor "conceder favores" a quem não é amado. Por outro, e de modo insinuante, o discurso quer convencer o rapaz apaixonado de que ele deve conceder favores a ele, Lísias, e não ao seu amado. Ele é, ao mesmo tempo, direcionado para provar uma tese que se aplica ao momento em que foi produzido e visa a um resultado prático como produto da persuasão. É um discurso pessoal que tenta parecer o contrário, uma persuasão direcionada a um caso particular que tenta se fazer passar por uma defesa de perspectiva geral, não interessada.

Sócrates mostra entusiasmo para ouvir a defesa de Lísias da tese do não amante. ${ }^{1} \mathrm{O}$ tom que precede à declamação do discurso é de fato cômico e lembra a conversa entre dois pretendentes. Enquanto Fedro simula certa indisposição em fazer o exercício de memória, Sócrates desnuda sua verdadeira intenção, acusando seu afã de proclamar de cor as palavras de Lísias como uma espécie de estado coribântico. O jogo entre

\footnotetext{
${ }^{1}$ Daqui em diante a perspectiva defendida por Lísias em seu discurso será nomeada como "tese do não amante".
} 
o não apaixonado e o apaixonado, tema do discurso de Lísias, já pode ser entrevisto na negociação socrática em ouvir as palavras decoradas. Sócrates se autodefine como amigo dos discursos e põe por terra as insinuações de Fedro, flagrando-o na mentira, ao levantar seu manto e descobrir escondido sob ele o discurso escrito de Lísias. Sócrates e Fedro caminham, então, por sugestão de Sócrates, para as margens do Rio Ilisso, fora dos muros da cidade. Em uma paisagem bucólica e com amena temperatura, ambos pretendem dar início à leitura do discurso de Lísias.

À primeira vista, o discurso atribuído a Lísias e declamado por Fedro versará sobre os malefícios que podem cercar uma relação amorosa quando o amado (erómenos) decide entregar-se aos desejos eróticos de um amante (erastés). O intuito do discurso de Lísias, dirigido a um suposto jovem, é o de convencê-lo de que é melhor "conceder seus favores" (kharizesthai) a alguém que não esteja apaixonado do que devotá-los a outro que se declare apaixonado. Na tradição clássica, o amante (erastés) geralmente é identificado como um homem mais velho que persegue com admiração o jovem, fazendo-lhe súplicas e pedidos. Erómenos, por sua vez, é o amado, o jovem que opta por se subordinar ao erastés e às suas vontades. ${ }^{2}$ Segundo Xenofonte (Hiero I, 37),

cada vez que um erómenos presta um serviço (hypourgein) a um cidadão particular, isso prova que ele está lhe concedendo tal favor (kharizesthai) por causa de afeto, porque o cidadão pode estar certo de que ele [o erómenos] está se subordinando (hypoterein) sem a imposição de qualquer obrigação; mas um tirano jamais pode ter certeza de que é amado. ${ }^{3}$

Levando em conta esse costume, tal como exemplificado pela passagem supracitada de Xenofonte, o discurso de Lísias tenta persuadir o seu "auditório" hipotético (qualquer erómenos, inclusive o próprio Fedro) de que é mais benéfico e proveitoso perverter a regra da concessão de favores e passar a adotar como princípio de prudência somente entregarse àqueles que não demonstrarem nenhuma paixão ou desejo erótico em

\footnotetext{
${ }^{2}$ A distinção dos termos relativos à condição e status da relação amorosa em "erómenos" e "erastés" não é exata; porém, optamos por seguir a nomenclatura escolhida por Dover (2007, p.34)

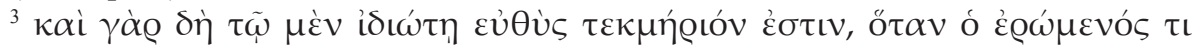

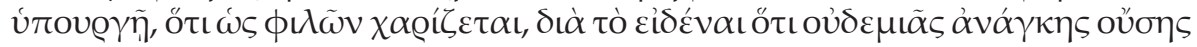

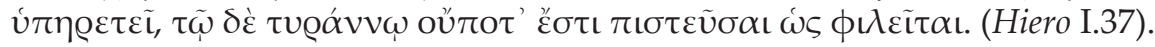


forma de súplicas. Trata-se, no sentido formal, de um discurso ao portador, ou seja, poderá ser utilizado por qualquer um que pretenda defender a tese de que é melhor conceder favores ao "não erastés" (não amante).

A introdução do discurso de Lísias tenta disfarçar sua verdadeira intenção. Lísias promete ao suposto erómenos que a verdade do seu discurso está garantida, dado que ele, o orador, desde o início declara em sua defesa não estar na condição de amante (Fedro 239a). Essa observação tem como pressuposto a ideia de que, quando o apaixonado, afetado pelo amor, discursa ou pronuncia algo, não se pode confiar no que ele diz. Ludibriante e insidioso é o lógos de Lísias, já que não há como descobrir se ele disse a verdade ou se, justamente por estar apaixonado e confirmando sua tese da não confiabilidade nas palavras do amante, pronunciou tal discurso apenas para persuadir Fedro, ou mesmo se é Fedro quem pretende persuadir Sócrates da tese do "não amante". Lísias busca cercar seu discurso livrando-o de qualquer acusação de pessoalidade, mas, como já vimos, não se trata de tema exato e objetivo, e a possibilidade de tudo ser um truque permanece quase como um efeito da linguagem, em conjunto com o sentido do seu conteúdo. Assegurar a validação moral do discurso, tipo de prova que Aristóteles identifica como caráter moral do orador, é um modo eficaz de iniciar um discurso, e é exatamente o que Lísias tenta fazer, garantindo seu distanciamento da questão. Ocorre, por sua vez, um efeito persuasivo em cascata. Dado que o discurso de Lísias defende a ideia de que é melhor "conceder favores" ao não apaixonado, e considerando que o orador desde o início garante sua isenção e indiferença em relação ao suposto jovem, para quem são endereçadas suas palavras, emerge do texto um efeito persuasivo indireto que o transforma, nesse sentido, em um "autoelogio" e uma defesa dos próprios interesses, sem que o ouvinte o perceba.

Dizer que um discurso tem veracidade porque é pronunciado por alguém que não está apaixonado já é pressupor que éros impede o conhecimento, e essa será uma das teses, senão a principal delas, refutadas pela palinódia socrática. Desde o início, o amor é visto como empecilho à verdade. Segundo o discurso de Lísias, o amante é por definição um indivíduo frívolo, que sai loucamente à procura do seu objeto de desejo, e quando finalmente o conquista não cumpre as promessas feitas quando buscava satisfazer-se (233a). O amante, quando dominado pelo afeto erótico, não diz a verdade, apenas manipula para conquistar o que quer. Éros é visto aqui como motivo do engano, do ludibrio e da vontade de possuir o outro, enquanto objeto amado, a qualquer preço. É curioso notar, 
no entanto, que a retórica procede exatamente mediante esse mecanismo de engano e aquele que não é capaz de ser enganado não poderá jamais ser persuadido. Na mesma direção, aquele que não é capaz de ludibriar e manipular o discurso, tendo em vista a gama infinita das paixões da alma e seu funcionamento, não poderá causar persuasão (MURRAY, 1988, p. 282). Explorando o discurso de Lísias, e a partir desse contexto, é possível considerar a retórica como instância erótica, na medida em que manipula para causar um efeito desejado.

$\mathrm{O}$ argumento desenvolvido é psicológico. $\mathrm{O}$ amante tomado pela paixão dedica-se tão profundamente ao objeto amado que se perde na profusão de seus afetos, a ponto de esquecer compromissos e deveres. Ao conquistar o objeto, deposita na conta do amado uma expectativa de gratidão por todas as coisas abdicadas em nome da satisfação do seu desejo (231b). A conta é extensa e o erómenos mal sabe, segundo Lísias, que sua promissória dificilmente será paga. Isso ocorre porque existe nessa negociação uma supervalorização daquilo que se fez e uma impossibilidade congênita do apaixonado em perceber a relação de maneira racional. O apaixonado sofre de uma suspensão da capacidade de raciocinar sobre a situação vivida e torna impossível qualquer diálogo pautado em critérios lógicos; por consequência, não sabe pensar sobre as melhores consequências de uma relação amorosa. Por outro lado, aqueles que não estão sob o jugo de éros dispensam o jogo de acerto de contas unilateral e podem aproveitar os melhores momentos ao lado um do outro. O erastés é caracterizado como incapaz de dominar-se; não tem domínio de si (enkrateia), possui uma alma doente e não pode ser considerado um amigo confiável (230c). Por ser frívolo e entusiasmado, nada garante que não possa trocar seu objeto de desejo, agora já possuído, descartando seu atual erómenos (Fedro 231d-e). O erastés está momentaneamente incapacitado de refletir com sensatez e mantém-se em estado de delírio, fazendo valer o sentimento de orgulho e a crença de que todos o invejam. Diante de tais condições e da desconstrução da ideia tradicional que permeia as relações entre o erastés e o erómenos, a peroração do discurso de Lísias passa a exortar seu ouvinte imaginário a optar pela entrega ao não amante, sábio e prudente por não sofrer os efeitos destruidores de éros. Essa figura imaginária do não amante não é tão abstrata assim, e o suposto menino almejado como auditório menos ainda. É Lísias tentando persuadir Fedro, o orador habilidoso usando de estratégias para possuir o jovem entusiasmado por suas palavras. 
O desejo, na perspectiva do discurso de Lísias, quando nascido do torpor da presença de éros, tem seu foco no corpo do amado (na beleza do corpo), distanciando-se do que é constante, como o caráter e suas condições estruturais determinantes. $\mathrm{Na}$ medida em que a beleza e a juventude, efêmeras por definição, desaparecem, o amante tende a abandonar seu objeto de desejo. Por oposição, na relação que dispensa voluntariamente éros, não existe tal risco, já que a amizade nasce antes do envolvimento sexual. O amante enamorado não é digno de confiança e quando elogia deseja apenas satisfazer seu desejo, deixando a verdade sobre o assunto de lado. Aqui Platão faz seu personagem Lísias descrever a própria retórica, pelo menos no seu gênero encomiástico, tão criticado no diálogo Menéxeno. Por meio do discurso de Lísias, criado por Platão, vislumbramos uma série de objeções à sofística. $\mathrm{O}$ interessante de se notar é que Platão, por intermédio da ficção, provoca no leitor um efeito crítico sobre a retórica sofística e o faz por meio do discurso de Lísias, supostamente fabricado pelo logógrafo. A ridicularização é automática e passível de ser percebida por intermédio do próprio discurso atribuído a Lísias.

\section{0 discurso de cabeça coberta (237a)}

O discurso de Lísias foi lido por Fedro e atentamente ouvido por Sócrates. Suas fissuras não serão evidenciadas de modo propositivo, pelo menos não imediatamente. A primeira etapa de sua refutação consiste em uma construção mimética realizada por Sócrates por meio de seu primeiro discurso. Sócrates repetirá o conteúdo de Lísias, mas, ao fazê-lo, modificará seu modo de compor. É na composição distinta que repousará o primeiro passo da refutação. A inventio (eùresis) socrática principia com uma invocação às Musas:

Vinde, Musas sonoras! Quer sejais assim chamadas pela qualidade de vosso canto, quer provenha dos sonorosos Lígures semelhante qualificativo. Cooperai comigo no discurso que este excelente moço me força (anankázó) a improvisar. ${ }^{4}$

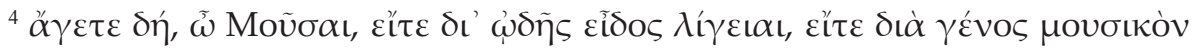

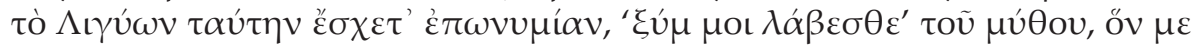

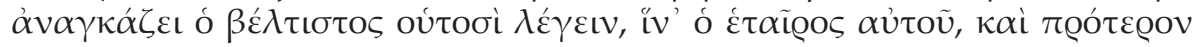
(Fedro 237a).
} 
O verbo anankázó (obrigar, compelir), utilizado no final da passagem, denuncia as condições de fabricação deste discurso, ou melhor, sugere como Platão deseja que o leitor compreenda o contexto de necessidade deste lógos contra o amor. A primeira fala socrática não é construída, portanto, com o objetivo de investigar o assunto, tal como ocorre na prática do élenkhos, mas para mostrar que o modo de compor discursos, tal como praticado por alguns oradores, além de não contribuir de maneira rigorosa para a aquisição de boas definições em torno de um problema, sequer é eficaz. É, portanto, forçoso nesse contexto que Sócrates construa um discurso de conteúdo semelhante, mas distinto na sua forma. Não importa aqui saber se Sócrates compartilha ou não da perspectiva de Lísias sobre o amor; importa mostrar que, a despeito de sua posição ser verdadeira ou não, o modo pelo qual esta é exposta supera em qualidade de persuasão o discurso de Lísias.

Platão, cujos diálogos têm a singularidade de levar o leitor a problematizar a relação entre forma e conteúdo, constrói ele mesmo dois discursos de conteúdos semelhantes e formas de apresentação diferentes. A construção dos dois discursos, aquele atribuído a Lísias e o primeiro de Sócrates, pronunciado com a cabeça coberta, parece contribuir para a ideia de ser possível separar, pelo menos de modo operacional, forma e conteúdo. É importante notar, no entanto, que, ao construir dois discursos de conteúdo similar e formatos diferentes, Platão também mostra no contexto do Fedro uma noção de que o lógos pode ser moldado criando novas realidades. O poder plasmador do lógos está tanto na criação de novas perspectivas a partir de um arranjo conveniente das palavras quanto na instrumentalização de um corpo de ideias que tem como finalidade mostrar que nem toda fabricação do discurso condiz com a verdade. Nesse sentido, Platão imita para criar dissenso e mostra que alguns usos do discurso não são eficazes e nem mesmo elaborados a partir de um desejo genuíno pelo conhecimento.

Duplicando oradores e sofistas, por meio da construção de personagens ao longo dos diálogos, as personae não falam somente em nome de Platão; falam segundo a necessidade que o contexto exige, significando vetores diversos acerca de temas propostos. A contradição, o jogo de vozes e o embate são constitutivos dessa filosofia, e, caso tentássemos reescrever os diálogos de maneira propositiva, perderíamos inevitavelmente sua singularidade e seu sentido. Francisco J. Gonzalez (1998) chega a dizer que somente entenderíamos de fato a filosofia 
de Platão produzindo outros diálogos para explicá-la. Fica claro aqui que forma e conteúdo não podem ser separados de maneira absoluta, mas apenas operatoriamente (GRISWOLD, 1986, p. 2). ${ }^{5}$ Sócrates dá prosseguimento ao discurso e o próximo passo é desqualificar o lógos de Lísias mediante a denúncia dos seus interesses pessoais, ao defender a tese de que é preferível conceder favores a quem não se ama. Segue a passagem que abre o segundo discurso:

Pois bem: houve outrora um rapaz belíssimo, ou melhor, houve um mancebo que tinha grande número de admiradores. Um destes era muito esperto. Ele, que realmente amava o rapaz como todos os outros, convenceu-o de que não o amava. Ao tentar conquistálo, esforçou-se por persuadi-lo de que antes se devem conceder favores aos que não ama do que ao apaixonado. Um dia dirigiulhe o seguinte discurso: em todas as coisas, meu rapaz, para que se tome uma resolução sábia é necessário saber sobre o que se delibera, pois, de outro modo, certamente nos enganamos. ${ }^{6}$

O discurso de Lísias utiliza a estratégia da isenção do orador, de sua imparcialidade diante do ponto defendido com a finalidade de conferir à sua defesa maior veracidade e confiabilidade. Ele garante ao suposto menino que não tem nenhum interesse na questão; Lísias diz não amar o menino e Fedro de maneira ingênua não entende a emboscada. A refutação socrática do discurso de Lísias ocorre em dois momentos. Primeiro Sócrates denuncia suas verdadeiras intenções, desautoriza seu discurso e a isenção do orador cai por terra; depois Sócrates constrói outro lógos que supera em eficácia a defesa de Lísias na medida em que se utiliza do lugar comum da definição.

\footnotetext{
${ }^{5}$ Segundo Griswold (1986, p. 2), “a máxima que orienta minha interpretação do Fedro é de que a forma do diálogo é intrínseca ao conteúdo de seu significado. O conteúdo do texto não é verdadeiramente compreensível fora de sua forma, e vice versa".

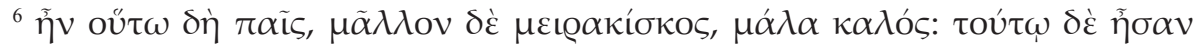

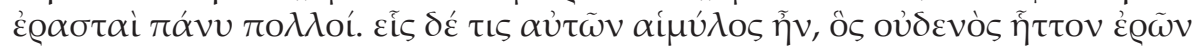

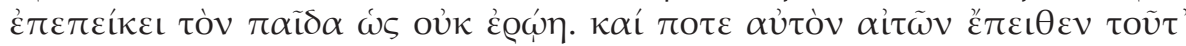

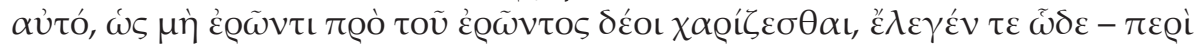

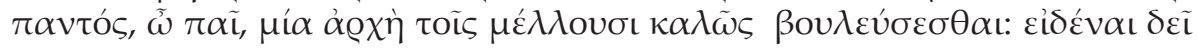

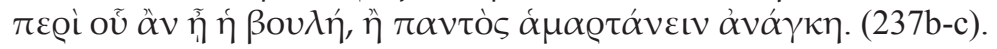


A próxima crítica não é menos incisiva e revela a obsessão socrática pela definição dos termos da discussão. Assim, Sócrates estabelece a sua regra de ouro.

[...] uma vez que nos propusemos a questão de saber se o amigo não apaixonado deve ter preferência sobre o que revela amor, assentemos desde já o que seja o amor e sua virtude peculiar, para, sem perdermos de vista nossa definição e a ela recorrendo quantas vezes for preciso, decidirmos se o amor é prejudicial ou benéfico. $(237 \mathrm{~d}){ }^{7}$

Ocorre aqui uma exigência do personagem Sócrates pela definição dos termos. A prática de definir os termos é tipicamente socrática e faz parte do procedimento refutativo conhecido como élenkhos. Nesse sentido poderíamos pensar que mesmo o primeiro discurso de Sócrates, refutado pelo próprio filósofo por meio da palinódia, já representa um pouco do próprio pensamento platônico. Em outros diálogos, notadamente aqueles chamados de socráticos, Platão por vezes faz do personagem Sócrates seu porta-voz. O leitor por vezes é levado a ver Sócrates como personagem central do filósofo, e a consequência de tal hábito é que se é levado quase sempre a uma leitura que não considera a polifonia do diálogo em sua real complexidade. Porém, no primeiro discurso de Sócrates, a exigência pela definição também é retórica. Ela não encadeia uma série de definições e encerra uma busca dialógica; é antes um artifício que confere seriedade ao discurso, um efeito de seriedade que produz confiabilidade. No segundo livro da Retórica, Aristóteles aponta a definição como um lugar-comum (tópos) argumentativo. Exigir a definição dos termos é um dos diversos modos de iniciar um discurso e confere certa veracidade para o assunto, como pode ser conferido nas seguintes passagens:

Outro [lugar-comum] obtém-se partindo da definição (horismoû). Por exemplo, o que é o divino (daimonión)? Um deus ou obra de um deus? Naturalmente, aquele que admitir que é obra de

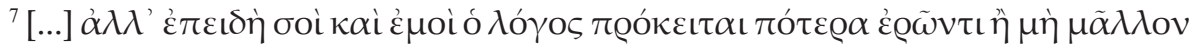

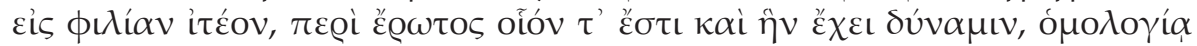

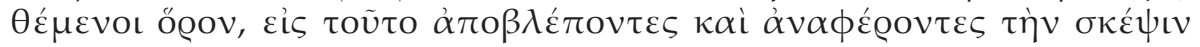

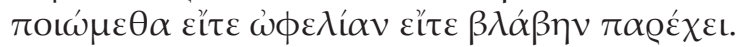


deus, forçosamente também há de admitir que os deuses existem (Retórica, 1398a, 15-16). ${ }^{8}$

Adiante, conclui Aristóteles:

[...] Todos esses casos constroem os seus silogismos sobre a matéria que tratam, partindo de definições e determinando a essência de uma coisa (Retórica, 1398a, 24-25). ${ }^{9}$

\section{A palinódia socrática: a refutação de Lísias}

Ao terminar seu primeiro discurso e ter decidido voltar para casa, Sócrates recebe um sinal que lhe é familiar (242 b-c): seu daimonión manifesta-se, dissuadindo-o de partir. Sócrates reconhece que não foi justo com éros e, para mostrar imediatamente seu arrependimento, cita o poeta Íbico: "De haver aos homens agradado, à custa de decurar dos deuses". ${ }^{10}$ Em seguida, declara: "agora sei em que consistiu o erro" (nûn d'e isthemai tò hamártema). Este é o sinal de que será necessário reparar o discurso e superar tanto aquele construído por Lísias e lido por Fedro quanto seu próprio lógos anterior. A bem da verdade, o primeiro discurso de Sócrates consistiu em uma estratégia retórica, como veremos adiante; porém, é preciso levar em conta que nessa ocasião o filósofo condenou os efeitos do amor de maneira ostensiva. O cálculo feito pela argumentação em torno da necessidade da palinódia repousa na ideia comum de que sendo Éros um deus, filho de Afrodite, pensá-lo como causador de males seria, de certa maneira, incorrer em impiedade. Baseado nessa pressuposição, de que dos deuses nada ruim pode advir, Sócrates retoma a palavra buscando retratar sua primeira perspectiva.

A invenção (inventio) da palinódia está definida. O filósofo resolveu retratar-se de sua posição acerca dos efeitos e das consequências do amor, considerando a premissa de que, sendo Éros um deus, não poderia causar males aos homens, mas apenas trazer-lhes benefícios e representar a verdade.

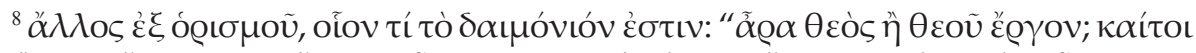

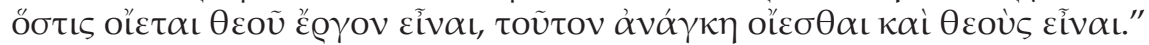

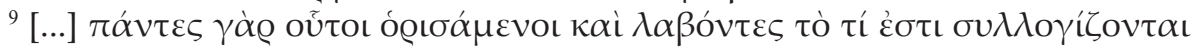

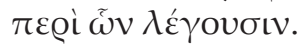

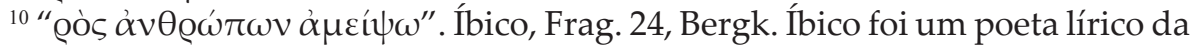
Magna Grécia. A ele é atribuído o gênero do elogio na poesia.
} 
A inventio é fornecida pela lírica de Íbico, e o início formal da retratação também faz menção direta à poesia, por meio da referência a Homero e Estesícoro. Em seu primeiro discurso, Sócrates também havia invocado as musas (Fedro 237a9). A citação direta do poeta Íbico, conhecido como criador do gênero laudatório, casa-se, por sua vez, perfeitamente com o início da palinódia, que é, fundamentalmente, encomiástico.

O evento da palinódia, tal como é apresentado inicialmente, pode ser visto a partir da ideia de que o discurso tem a capacidade de purificar o pensamento e mesmo algumas ações. Seguindo o texto de perto, vemos que um dos objetivos declarados no início da retratação é o de fazer justiça aos deuses e tornar novamente limpa e pura a figura de Sócrates, enquanto autor de um discurso ímpio. A passagem que compara a conhecida ${ }^{11}$ palinódia de Estesícoro, ressaltando seu efeito purificador (kátharmos) e restaurador da visão deste poeta, com a retratação filosófica que Sócrates construirá em seguida para fazer justiça a Éros, sugere a existência de uma função catártica para o discurso. Assim, a partir de $243 \mathrm{a}-\mathrm{b}$, pensamos que a palavra assume uma função mágica de curar um estado equivocado das coisas. Impossível não lembrar aqui da ideia de que o discurso é um medicamento que faz depender sua eficácia da dosagem em que é ministrado:

Para os que cometem erro de mitologia, há uma antiga purificação que passou despercebida a Homero, não, porém, a Estesícoro. Privado da vista por haver difamado Helena, não lhe escapou, como a Homero, a causa de semelhante fato; por frequentar as Musas, reconheceu-a e, de pronto, compôs os versos: "Foi mentira quanto eu disse/ Nunca subiste nas naves/ de belas proas recurvas/ nem no castelo de Tróia/ jamais pisastes algum dia". Havendo escrito nesse estilo toda a palinódia, imediatamente recuperou a vista. De minha parte, quero mostrar-me mais sábio do que ambos; neste ponto, pelo menos. Antes de cair sobre mim alguma desgraça por haver falado mal de Éros, vou apresentar-lhe minha retratação,

\footnotetext{
${ }^{11}$ A história de Estesícoro e sua visão recuperada após a palinódia é recorrente e parece ser de conhecimento comum na época. Platão cita o poeta em dois momentos (Fedro 243a; República 586c, de maneira indireta). Isócrates também menciona a mesma história no seu Elogio de Helena, 64.
} 
e isso de cabeça descoberta, não velada, como a vergonha a pouco me obrigou a proceder. ${ }^{12}$

Assim, a purificação socrática ocorrerá por meio da palavra e esta, conforme a promessa inicial, deverá mostrar os erros cometidos em seu primeiro discurso. Literariamente, a construção da palinódia tem um objetivo pessoal para Sócrates, na medida em que ele preocupa-se com punições da divindade pelo seu ato ímpio. No entanto, sabe-se que a preocupação de Platão aqui diz respeito à refutação de Lísias e esta será feita de modo indireto, por intermédio da pseudorefutação do próprio Sócrates, habilmente construída por ele mesmo. Ao construir uma refutação de si mesmo, Sócrates acaba por refutar Lísias, considerando que o pressuposto que sustenta ambos os discursos é o mesmo, a saber, de que é preferível relacionar-se com um parceiro não apaixonado, visto que o amor e a paixão causam nos homens um estado doentio.

A exposição da fragilidade do discurso de Lísias, lido por Fedro, é composta de elementos textuais, cênicos e simbólicos. A cabeça de Sócrates agora está descoberta (243b) e esse é a primeira pista literária que indica o aspecto artificial e estratégico de seu primeiro discurso. Sabendo que havia composto um discurso descolado de suas convicções pessoais, o personagem Sócrates é levado a mostrar sua insatisfação por meio da sua voz "demoníaca", que o impede de prosseguir sem terminar o que deve fazer. Outra pista de que o primeiro discurso de Lísias não tem significado completo se for considerado isoladamente, mas apenas na medida em que antecede a sua refutação, é a presença do daimon, que sempre sugere uma continuidade do diálogo, impedindo sua interrupção e exigindo uma reformulação do problema. Assim, a defesa do não amante, realizada por Sócrates logo após a leitura do discurso de Lísias com conteúdo similar, deve ser compreendida como o passo necessário para a exposição dos

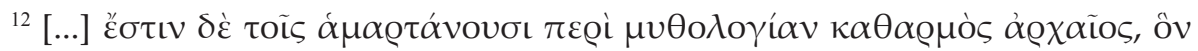

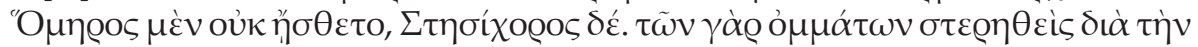

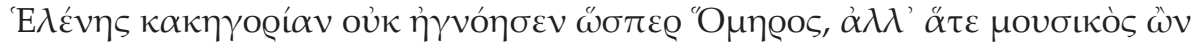

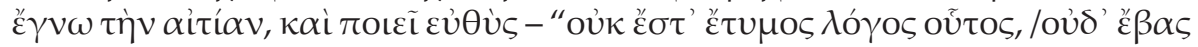

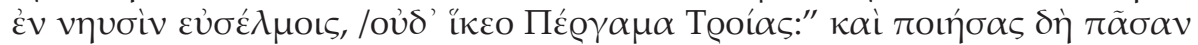

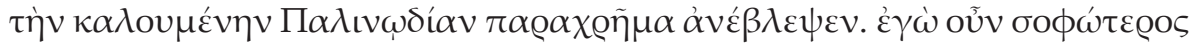

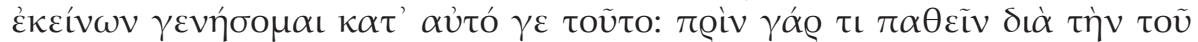

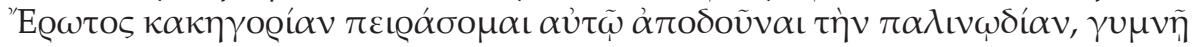

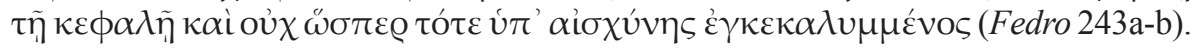


argumentos contidos na palinódia. Trata-se de uma refinada estratégia de ampliação da crítica e da potência refutativa do discurso, na medida em que supera o primeiro discurso tanto em seu aspecto formal quanto em seu conteúdo. O saldo é a crítica aos dois primeiros discursos em seu conteúdo defendido, a denúncia da pouca habilidade de Lísias (dos "Lísias", dos logógrafos) com relação à composição e organização dos argumentos, e a consagração de Sócrates (dos "Sócrates", dos filósofos) como melhor orador, compositor de discursos e conhecedor do objeto tratado. Aliás, o terceiro atributo é a causa e origem dos dois primeiros. É justamente por conhecer melhor, investigar mediante um método mais acurado e procurar a resposta para questões fundamentais de maneira dialética que o filósofo é melhor com a persuasão do que os oradores. Essa é a tese que a segunda parte do Fedro tentará mostrar.

Em 243 e, fica claro que o suposto jovem para quem o discurso de Lísias foi construído, o jovem hipotético, era de fato o próprio Fedro. Esse mesmo jovem agora está disposto a ouvir a retratação realizada por Sócrates. O belo menino será auditório de Sócrates, e o leitor atento é o auditório de Platão. A palinódia socrática terá como fundamento a revisão do conceito de delírio (manía). De acordo com a tese defendida por Lísias e repetida por Sócrates em seu primeiro discurso, o amor provoca um delírio que apenas traz prejuízo para o amado em suas relações cotidianas, pois retira de cena a razão e faz com que as pessoas tomem atitudes imprudentes. O primeiro passo da retratação é reabilitar o delírio, buscando mostrar que em algumas ocasiões ele não somente é bem-vindo, mas necessário. $\mathrm{O}$ argumento pode ser exposto da seguinte maneira: se o delírio não é um mal em si, ou seja, se existe a possibilidade de se significar positivamente o delírio, então a ideia de que o amor deve ser afastado unicamente por se tratar de uma espécie de delírio não se sustenta. Será preciso verificar se, de fato, o amor é um delírio ruim ou se na verdade trata-se de uma forma benéfica de "loucura". Para Sócrates, a espécie de delírio (manía) da qual participa o amor "nos foi dada pelos deuses para a nossa maior felicidade (eutykhíai - 245 b)". No entanto, o ponto não está provado e, para fazê-lo, Sócrates deverá iniciar um longo percurso acerca da natureza da alma. Segundo o próprio Sócrates, a demonstração (apódeixis) da existência de manías benéficas ao ser humano consiste em "alcançar a verdade a respeito da alma humana".

O início da demonstração é abrupto e exibe imediatamente uma tese robusta e de difícil comprovação: "a alma toda é imortal" 
(psykhè pása athánatos - 245c) e isso ocorre porque ela é automovente (aeikíneton), possui força motriz, não necessitando de nada externo e ou que lhe seja heterogêneo no ato do movimento. ${ }^{13}$ Segundo Sócrates, o delírio erótico não é um mal e nem mesmo deve ser evitado, mas configura-se como uma dádiva que "[...] foi dada pelos deuses para nossa maior felicidade" (245c). ${ }^{14}$ Tal ideia deverá ser bem desenvolvida para que a refutação do discurso de Lísias ocorra, bem como para mostrar que a alma é o objeto por excelência das investigações filosóficas.

Considerando que o discurso de Lísias ampara-se justamente na ideia de que todos os delírios, inclusive aquele provocado pelo amor, são nefastos ao homem, Sócrates tentará mostrar o contrário a fim de desqualificar sua argumentação. A apresentação acerca da imortalidade da alma (245c-246a) baseia-se na divisão entre seres que são movidos e seres que se movem, ou seja, existem seres que necessitam de uma força motor externa para gerar o movimento e a vida e seres que têm a propriedade de se automoverem, não necessitando de nada que lhes seja distinto. Aquilo que não necessita de uma força motor externa tem vida própria e escapa a qualquer lógica sustentada pelos conceitos de geração e corrupção. Seres gerados são mortais, dado que vieram a existir por meio da geração, porém seres que não foram gerados, aqueles que contam com força motora própria, não estão expostos à corrupção e são, por esse motivo, imortais. Nesse instante da argumentação nada é demonstrado de maneira clara. Sócrates afirma a relação necessária entre geração/corrupção e mortalidade e entre não geração/não corrupção e imortalidade, mas não mostra a relação de necessidade entre alma e imortalidade. Ocorre aqui uma aposta argumentativa: se realmente for possível mostrar que a alma pertence ao grupo das coisas que geram o próprio movimento, há a possibilidade de pensá-la como uma exceção à lógica da geração e corrupção dos seres e, portanto, caracterizá-la como imortal. $\mathrm{O}$ argumento da imortalidade da alma pode ser visto como pertencente à instância do verossímil e não do verdadeiro (NEHAMAS; WOODRUFF, 1998, p. 30). Escapa, portanto, das exigências lógicas,

${ }^{13} \mathrm{O}$ argumento apresentado acerca da imortalidade da alma, segundo Nehamas e Woodruff, foi apresentado na Antiguidade pelo filósofo Alcmeon de Crotona, um pitagórico do início do quinto século. (NEHAMAS; WOODRUFF, 1998, p. 29, nota 63).

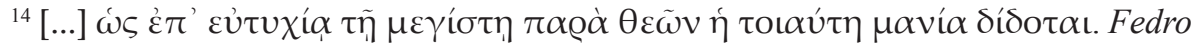
$245 \mathrm{c}$. 
aproximando-se de uma ideia geral e adotando uma crença comumente aceita sobre a relação entre corrupção/geração e mortalidade e entre não corrupção/não geração e imortalidade.

Lançada a hipótese de trabalho que deverá sustentar a refutação de Lísias, o lógos socrático parte para a caracterização da natureza da alma. Pressupondo, mesmo que ainda de maneira conjectural, que a alma seja imortal, é preciso pensar sua constituição, seu modo de funcionamento. A partir de 246a, o discurso de Sócrates resolve abandonar as longas narrativas (makrâs diégeseses) e passa novamente a usar o recurso da imagem. Sócrates passa à narrativa da alma assumindo que é oportuno usar imagens nessa empreitada e justificando o uso do recurso por se tratar de assunto muito complexo e de difícil abordagem. Pois bem, é dessa maneira que o filósofo prefere se expressar, por meio de imagens, analogias e estórias fantásticas. Falando de modo adequado à situação, Sócrates diz:

[A alma] assemelha-se (éoiketo ) a uma força natural composta de uma parelha de cavalos alados e seu cocheiro. Os cavalos dos deuses e os respectivos aurigas são bons (agathoi) e de elementos nobres, porém os dos outros seres são compósitos (mémeiktai)"15.

O primeiro ponto do seu discurso acerca da natureza da alma já adianta pelo menos duas ideias importantes: a alma humana, na visão que será desenvolvida adiante, é formada por três partes, não sendo composta apenas de elementos nobres, mas misturada (mémeiktai). A parelha (a alma) é desigual. Um dos cavalos é belo, nobre e de boa origem (agathós), enquanto o outro é rude e preguiçoso, sendo que dessa mistura surge a dificuldade do controle das rédeas e da direção da parelha pelo condutor. Na imagem construída por Platão, a parelha alada que, por sua vez, corresponde à estrutura da alma humana, é desigual.

A imagem da parelha alada com seu respectivo cocheiro remete à ideia de que a alma é imortal devido ao seu caráter "automovente". Nesse momento há um esforço e um direcionamento claro no discurso socrático em utilizar termos ligados à ideia de movimento. As forças díspares da alma, uma força que eleva e a outra que rebaixa; o cavalo nobre e o cavalo vulgar, a boa tração, ordenada e direcionável, oposta

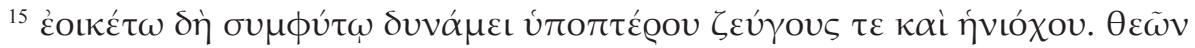

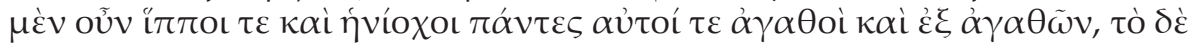

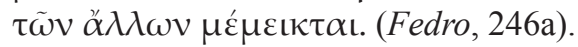


à tração violenta, sem rumo e impulsiva compõem as metáforas desta narrativa e remetem sempre às ideias de movimento e ritmo. O controle das forças anímicas é descrito a partir do equilíbrio daquilo que sempre está em movimento. Ela própria, a alma, é caracterizada como portadora de asas, capaz de gerar movimento.

Em uma escala de nove graus são dispostos o modo de vida de cada indivíduo, bem como os ofícios praticados e seu respectivo nível de esclarecimento em relação às essências (248d-e). Partindo daquele que mais contemplou as essências em direção ao que menos contemplou, temse o seguinte quadro: 1) o amigo da sabedoria (philósophos), o amigo da beleza (philókalos), o músico (mousikós) e o amante (erotikós); 2) o rei legitimado pela lei (basiléos egnómou), o comandante bélico (polemikós kaì arkhikós); 3) o político (politikós), o economista (oikonomikós), o negociante (khrematistikós); 4) o ginasta (gumnastikou), o treinador físico; 5) o adivinho ou iniciado nos mistérios; 6) o poeta/com capacidade criativa (poietikós) e aqueles capazes de imitação (mímesis); 7) o artesão (demiourgikós) e o agricultor (georgikós); 8) o sofista (sophistikós) e o demagogo (demokópos); 9) o tirano (tyrannikós).

Em relação à primeira posição da divisão tipológica, dividida entre o filósofo, o músico e o amante, faz-se necessário um breve esclarecimento. Segundo Hackforth (1972, p. 83), a presença do músico dividindo lugar com o filósofo deve ser compreendida como uma expressão dupla do mesmo modo de vida. Nesse sentido, trata-se de um filósofo também afeito à música. Quanto ao terceiro tipo, o amante, o restante da estória contida na palinódia se encarregará de esclarecer. Se o principal objetivo da palinódia é alcançar a refutação do discurso de Lísias, tal tarefa dependerá fundamentalmente da demonstração sobre a posição de destaque ocupada pelo amante na tipologia humana. A segunda classe de almas, as que se destinam aos governantes legítimos e comandantes bélicos, corrobora, segundo Hackforth (1972, p.83), a posição adotada no Político (297d-302e).

A refutação de Lísias começa no primeiro discurso de Sócrates que, apesar de também ser alvo de refutação pela palinódia, cumpre um papel importante ao denunciar a pouca habilidade do logógrafo em compor o seu discurso, consolidando uma espécie de crítica estética ao texto de Lísias. O primeiro discurso de Sócrates opera duas críticas diretas ao logógrafo: inicialmente, afirma a falta de destreza do orador em organizar o discurso e, em seguida, o desqualifica moralmente 
denunciando seu envolvimento afetivo com Fedro, que é o seu auditório específico. Além de efetuar essa dupla crítica, pensamos que o objetivo pretendido ao iniciar o Fedro com um discurso pronto, escondido sob o manto de um jovem, escrito, sem a presença de seu autor, para ser lido e repetido por outrem, é o de adiantar literal e dramaticamente a crítica à logografia, além de exaltar a preferência do filósofo pela investigação dialógica e genuína, colada vitalmente àquele que se propõe a pensar determinado objeto. O Fedro todo, se considerado como um discurso único, respeita as regras de composição de discursos defendidas pelo personagem Sócrates no mesmo diálogo (264c). Ele deve ser organizado (synístemi - 264c) harmonicamente, o que significa dizer que todas as suas partes se relacionam.

A necessidade da composição da palinódia é claramente justificada por Sócrates, pelo menos em um primeiro nível de leitura, como uma espécie de obrigação moral em desculpar-se com a divindade, um ato de piedade, no sentido que essa virtude tem para os gregos, ou seja, o de respeitar e cultuar os deuses. Ela se inicia com a tarefa assumida por Sócrates em mostrar que a tese de Lísias, de que o delírio causado pelo amor é prejudicial ao homem, na medida em que o retira de sua condição racional, está errada. O erro consiste, segundo Sócrates, na atribuição de todos os males ao delírio erótico e também em condenar todos os outros tipos de delírio como nefastos.

Em meio a uma descrição da alma dos deuses, Sócrates estabelece uma escala de valores, imageticamente justificados, dos tipos humanos e suas funções na cidade, baseada no grau de vislumbre da justiça e da temperança na mítica planície da alétheia. Pois bem, se estamos de acordo que Lísias é um orador e logógrafo, tido na conta de sofista, há aqui uma deliberada exposição da sua capacidade de compreensão da verdade. Lísias está em oitavo lugar na escala tipológica, somente perdendo para o tirano, o tipo mais criticado por Platão. Se o discurso já havia sido denunciado como mal composto, mais ainda, se seu autor já havia sido apontado como interessado em aproveitar-se pessoalmente da persuasão pretendida e se a sua tese basilar sobre as consequências nefastas do delírio está a caminho de ser desmentida, agora o próprio ofício atribuído por Lísias, o de orador e sofista, é desqualificado e naturalizado como inferior ao modo de vida do filósofo, que ocupa, por sua vez, o primeiro lugar na escala valorativa. Em resumo, Sócrates está sete graus à frente de Lísias no que diz respeito ao grau de vislumbre das ideias de justiça 
e temperança. Enfim, Sócrates é melhor do que Lísias, e é natural que seu discurso possa refutar com propriedade o lógos do orador. Há uma autoridade maior na refutação que parte de um princípio valorativo, princípio esse fundamentado na escolha do melhor modo de vida. Essa conclusão parece simplista e o é se não for acompanhada da exposição de toda a argumentação lógica e imagética da palinódia. A palinódia tem um mecanismo gerador de um duplo efeito. Articulada à refutação e à censura de Lísias surge, quase que instantaneamente, uma espécie de defesa e elogio da vida filosófica. Assim, ao mostrar as deficiências do orador, o mito da parelha alada alcança um objetivo indireto, mas não menos importante, que é o de caracterizar e explicar quem é o filósofo.

Considerando os argumentos apresentados acima, reiteramos o objetivo de oferecer uma leitura geral dos três discursos sobre éros, localizados na primeira parte do Fedro, a fim de mostrar que o embate entre as diferentes perspectivas sobre o amor marca que a temática da retórica une-se à do amor para conferir unidade ao Fedro. Isso ocorre por meio da identificação do motivo da escolha pelo assunto e também pela relação que a temática mantém com a prática da retórica e da filosofia. $\mathrm{O}$ modo como ocorrem os três discursos sobre éros denota uma preocupação clara do filósofo em apresentar a possibilidade de distinção entre forma de apresentação dos argumentos e conteúdo veiculado. Já no embate entre os três discursos, observa-se que as temáticas da retórica e da refutação, ou seja, da superação de um discurso por outro, melhor, mais eficaz e mais verdadeiro, são contempladas e deverão ser justificadas na segunda parte do Fedro. Já na construção da palinódia, o filósofo promove uma inversão da tese de Lísias, atacando sua perspectiva pejorativa sobre os efeitos do amor e justificando, ao mesmo tempo, por intermédio da narrativa sobre a alma, a necessidade de que o orador tenha o prévio conhecimento do modo como cada alma se afeta. Para conhecer o modo de funcionamento de cada alma, o orador deve investigar o que é a alma, como ela é composta e de que modo ela pode ser afetada. Assim, para ser um bom orador, para persuadir verdadeiramente, será necessário filosofar, investigar o que é característico da alma e como ela se afeta. Antes de buscar a persuasão, portanto, o orador precisa certificar-se de que consegue fornecer definições sobre o assunto tratado e obter, previamente, o conhecimento sobre as condições que pressupõe o direcionamento de cada discurso a determinado auditório. A partir desse quadro, éros é parte fundante de toda tarefa cognitiva, de toda filosofia, enquanto 
procedimento discursivo que caminha em direção às definições e também de toda retórica, enquanto técnica de pressupor corretamente para quais tipos de alma esses mesmos discursos serão direcionados.

\section{Referências}

ARISTÓTELES. Retórica. Trad. e notas de M. Alexandre Jr., P. F. Alberto e A. N. Pena. Lisboa: Imprensa Nacional/Casa da Moeda, 1998.

GOGGIN, M. D.; LONG, E. A Tincture of Philosophy, A Tincture of Hope: The Portrayal of Isocrates in Plato's Phaedrus. Rhetoric Review, New York, n. 11, v. 2, p. 301-324, 1993.

GONZALEZ. F. J. Dialectic and Dialogue. Plato's Practice of Philosophical Inquiry. Evanston: Northwestern University Press, 1998.

GRISWOLD, C. L. Self-knowledge in Plato's Phaedrus. New Haven/ London: Yale Univ. Press, 1986.

JAEGER, W. Paidéia: A formação do homem grego. Trad. Artur Parreira. Sao Paulo: Martins Fontes, 2001.

MURRAY, J. S. Disputation, deception, and dialectic: Plato on the True Rhetoric (Phaedrus 261-266). Philosophy and Rhetoric, London, v. 21, n. 4, p. 279-289, 1988.

PLATÃO. Fedro. Trad. Carlos Alberto Nunes. Belém: UFPA, 2011.

PLATO. Phaedrus. Translated with Introduction \& notes by Alexander Nehamas \& Paul Woodruff. Indianapolis/Cambridge: Hackett Publishing Company, 1998.

PLATO. Phaedrus. Translated with Introduction and Commentary by R. Hackforth, Cambridge: 1952.

PLATO. Plato's Gorgias: a revised text with introduction by E. R. Dodds. Cambridge: Cambridge University Press, 1959. 